\title{
DNA microsatellite analysis of families with autosomal dominant polycystic kidney disease types 1 and 2: evaluation of clinical heterogeneity between both forms of the disease
}

Eliecer Coto, S Sanz de Castro, S Aguado, J Alvarez, M Arias, M J Menéndez, C López-Larrea

\begin{abstract}
We studied 17 large families affected by adult dominant polycystic kidney disease (ADPKD). Ultrasonographic analysis was performed on all the family members. DNA microsatellite markers closely linked to PKD1 on 16 p13.3 were analysed, and linkage of the disease to this locus was determined. Families showing a negative linkage value were evaluated for linkage to the PKD2 locus on 4q.

Five of the 17 families showed negative linkage for the $16 \mathrm{p} 13.3$ markers. In these families significant linkage to $4 q$ was obtained. Renal cysts developed at an earlier age in PKD1 mutation carriers, and end stage renal failure occurred at an older age in people affected with PKD2.

Analysis of large families with ADPKD in a Spanish population indicates that this is a genetically heterogeneous disorder, but mutations at only two loci are responsible for the development of the disease in most if not all the families. Clinicopathological differences between both forms of the disease occur, with subjects with ADPKD2 having a better prognosis than those with mutations at PKD1.
\end{abstract}

( $(\mathcal{H}$ Med Genet 1995;32:442-445)

Autosomal dominant polycystic kidney disease (ADPKD) has a prevalence of about 1 in 1000, accounting for 8 to $10 \%$ of cases of end stage renal failure. ADPKD may occur at any time in life, and is characterised by cyst formation in the kidney and, to a lesser extent, in the liver. Other gastrointestinal and cardiovascular abnormalities are often found in ADPKD patients. Renal cysts are detected by ultrasonography, with a probability that increases with age. Several studies have described the presence of cysts in most mutation carriers by the age of 30 years, while some of the carriers younger than 30 years remain asymptomatic. ${ }^{12}$

Linkage analysis on affected families showed the existence of at least two loci involved in this disease. About $90 \%$ of the families showed positive linkage to markers on $16 \mathrm{p} 13.3 .^{3-6}$ The PKD1 gene on $16 \mathrm{p}$ has recently been isolated and partially characterised. ${ }^{7}$ Mutations at PKD1 define the classical form of the disease, also known as ADPKD1. Several DNA poly- morphic markers flanking PKD1 have been described. ${ }^{8-10} \mathrm{~A}$ second ADPKD locus has recently been mapped to $4 \mathrm{q} 21 .{ }^{112}$ Microsatellites flanking this second locus, designated PKD2, have been described. Mutations in the PKD2 gene are responsible for an alternative, less frequent, form of the disease, designated ADPKD2. ${ }^{1314}$ Several studies have suggested that the genetic heterogeneity that characterises ADPKD has corresponding phenotypic heterogeneity. Cysts are apparently detected at an older age in those patients having the alternative form of the disease than in those who have the classical ADPKD1 form. ${ }^{1516}$

We have analysed 17 large Spanish families with several microsatellite markers around PKD1 and PKD2 in an attempt to define the linkage of the disease to these loci, the existence of further genetic heterogeneity, and to compare the clinical course of ADPKD1 and ADPKD2 patients.

\section{Methods \\ FAMILIES}

Seventeen large families affected by ADPKD were studied. Family members were ultrasonographically evaluated, with symptomatic affected subjects showing at least one cyst in one kidney and at least two cysts in the other kidney. A family was considered to be large (for linkage analysis purposes) when at least three affected members and two unaffected children (older than 30 years) of an affected member were available. This minimum criterion was established by the European Concerted Action on ADPKD. A total of 188 members of the 17 families had an affected parent, thus being at risk of having ADPKD. All family members at risk of having ADPKD were ultrasonographically evaluated during 1993.

DNA MICROSATELLITE ANALYSIS

DNA was obtained from each subject. Four microsatellite polymorphisms ((CA)n repeats) around the PKD1 gene on $16 \mathrm{p} 13.3$ were studied (fig 1). AC2.5 (D16S291) ${ }^{17}$ and SM7 $(\mathrm{D} 16 \mathrm{~S} 284)^{9}$ have a proximal location relative to PKD1 (fig 1). KG8 is located intragenic, at the $3^{\prime}$ end of the PKD1 gene. ${ }^{7} \mathrm{D} 16 \mathrm{~S} 521$ is a subtelomeric microsatellite. ${ }^{8}$ Four microsatellites on 4q21 (D4S395, D4S414, D4S423, 

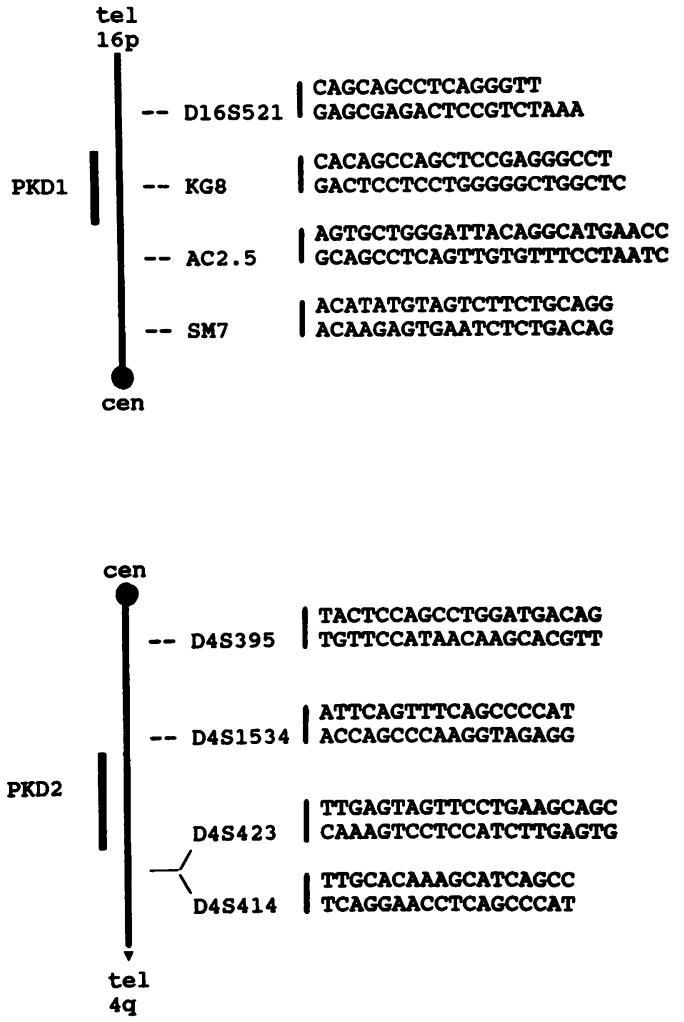

Figure 1 Map of the microsatellite markers around the $P K D 1$ (16p13.3) and PKD2 (4q21) genes.

and D4S1534) were analysed in those families that showed negative linkage to the $16 \mathrm{p}$ markers $^{1112}$ (fig 1).

PCR consisted of $100 \mathrm{ng}$ of genomic DNA in a final volume of $10 \mu \mathrm{l}$ containing $50 \mathrm{mmol} / 1 \mathrm{KCl}, 10 \mathrm{mmol} / 1$ Tris- $\mathrm{HCl}$ (pH 8.5), $200 \mu \mathrm{mol} / 1$ of each dATP, dGTP, and dTTP, $100 \mu \mathrm{mol} / 1$ of $\mathrm{dCTP}, 0 \cdot 1 \mu \mathrm{Ci}$ of ${ }^{32} \mathrm{P}$-dCTP $(3000 \mathrm{Ci} / \mathrm{mmol}$, Amersham), $10 \mathrm{pmol}$ of each primer (fig 1), $2.0 \mathrm{mmol} / 1 \mathrm{MgCl}_{2}$, and 1 unit of Taq polymerase (Promega). After an initial denaturing step (three minutes, $98^{\circ} \mathrm{C}$ ) the microsatellite sequence was amplified by 30 cycles of $98^{\circ} \mathrm{C}$ for 30 seconds, the annealing temperature for 30 seconds, and an extension of $72^{\circ} \mathrm{C}$ for 30 seconds. A final extension step for five minutes at $72^{\circ} \mathrm{C}$ was performed. Annealing temperature was $59^{\circ} \mathrm{C}$ except for AC2.5 which was annealed at $65^{\circ} \mathrm{C}$.

Ten $\mu$ l of formamide loading buffer (95\% formamide, xylene cyanol) were mixed with the PCR reaction and this mixture was heated at $98^{\circ} \mathrm{C}$ for five minutes. Five $\mu \mathrm{l}$ were loaded onto a $40 \mathrm{~cm}$ long $6 \%$ denaturing sequencing gel (acrylamide $5 \cdot 7 \%$, bis-acrylamide $0 \cdot 3 \%$, urea $45 \%$ ). Gels were run with TBE buffer (Tris- $\mathrm{HCl} 90 \mathrm{mmol} / \mathrm{l}$, boric acid $90 \mathrm{mmol} / 1$, EDTA $2.5 \mathrm{mmol} / \mathrm{l}$ ) under denaturing conditions, vacuum dried, and autoradiographed for two hours to one day.

LINKAGE

Linkage analyses were performed on the 17 families. The decimal logarithm of the odds ratio for linkage (lod score, $Z$ ) was obtained for different recombination frequencies $(\theta)$ using the LINKAGE program. ${ }^{1819}$ Fisher's exact test was used to compare the age at cyst development, the age at onset of end stage renal failure, and the incidence of hypertension in subjects with ADPKD1 and those with ADPKD2.

\section{Results}

Positive linkage to $16 \mathrm{p} 13.3$ markers was found in 12 of the 17 families (table 1). Because the AC2.5, SM7, or KG8 microsatellites were informative in all the families, and these loci did not recombine with PKD1, the maximum lod score values were obtained at the null recombination fraction, with the lowest lod score in any family estimated as being 1.35. This value represents a probability in favour of linkage of 44 to 1 . Eight different AC2.5-SM7KG8 haplotypes were found in the 12 PKD1 families. A negative lod score for $16 \mathrm{p} 13$ was obtained in five of the families. These nonPKD1 families had positive values for linkage to the $4 \mathrm{q} 21$ markers. Haplotypes defined by the $4 \mathrm{q}$ loci were constructed, and the lowest lod score for linkage was estimated as being 1.57 , representing a probability in favour of the $4 \mathrm{q}$ linkage of 37 to 1 (table 1). Examples of ADPKD1 and ADPKD2 families are shown in fig 2. In one of the ADPKD2 families a recombination located the PKD2 locus between D4S1534 and D4S414 (fig 2).

A total of 77 people in the 12 ADPKD1 families were carriers of the disease (DNA analysis). Sixty-one of these were older than 21 years and all of them showed ultrasonographic renal cysts. Twenty five of the ADPKD1 affected subjects had end stage renal disease, with the earliest age at onset at 32 years (mean age $47 \cdot 6$, SD 10.3). A total of 36 subjects in the five ADPKD2 families were carriers of the disease, and cysts were also present in all carriers older than 21 years (30 people). Six ADPKD2 patients had end stage renal disease, with the earliest age at onset at 44 years (mean age $56 \cdot 3$ years, SD 7 ).

Table 2 summarises the data on the age of mutation carriers and the presence of cysts, the age at onset of end stage renal disease, and the incidence of hypertension in our patients. Comparison of these clinical parameters between ADPKD1 and ADPKD2 patients

Table 1 At risk subjects, number of mutation carriers, and maximum lod score values for each of the 12 and maximum lod score values for each
$A D P K D 1$ and five ADPKD2 kindreds

\begin{tabular}{|c|c|c|c|}
\hline & $\begin{array}{l}\text { At risk } \\
\text { members }\end{array}$ & $\begin{array}{l}\text { Mutation } \\
\text { carriers }\end{array}$ & $\begin{array}{l}\text { Linkage analysis } \\
(\operatorname{marker} / Z \max (\theta))\end{array}$ \\
\hline \multicolumn{4}{|c|}{ ADPKD1 families } \\
\hline 1 & 15 & 10 & $\mathrm{AC} 2.5 / 2.89(0.0)$ \\
\hline 2 & 12 & 6 & $\mathrm{AC} 2.5 / 1.90(0.0)$ \\
\hline 3 & 8 & 6 & D $16 S 521 / 2 \cdot 10(0 \cdot 0)$ \\
\hline 4 & 8 & 6 & SM7/1.98 (0.0) \\
\hline 5 & 7 & 4 & SM $7 / 1.65(0.0)$ \\
\hline 6 & 11 & 5 & AC $2.5 / 1.35(0.0)$ \\
\hline 7 & 9 & 3 & KG8/1.75 (0.0) \\
\hline 8 & 6 & 5 & $\mathrm{AC} 2.5 / 1 \cdot 81(0.0)$ \\
\hline 9 & 13 & 8 & AC $2.5 / 2.25(0.0)$ \\
\hline 10 & 7 & 5 & SM7/1.80 (0.0) \\
\hline 11 & 19 & 12 & AC2.5/3.36 (0.0) \\
\hline 12 & 7 & 7 & SM7/1.80 (0.0) \\
\hline \multicolumn{4}{|c|}{ ADPKD2 families } \\
\hline 13 & 21 & 12 & D4S1534/4.43(0.0) \\
\hline 14 & 16 & 6 & D4S414/2.06(0.0) \\
\hline 15 & 16 & 8 & D4S1534/2.57(0.0) \\
\hline 16 & 10 & 5 & D4S1534/1.98(0.0) \\
\hline 17 & 9 & 5 & $\mathrm{D} 4 \mathrm{~S} 395 / 1.57(0.0)$ \\
\hline
\end{tabular}



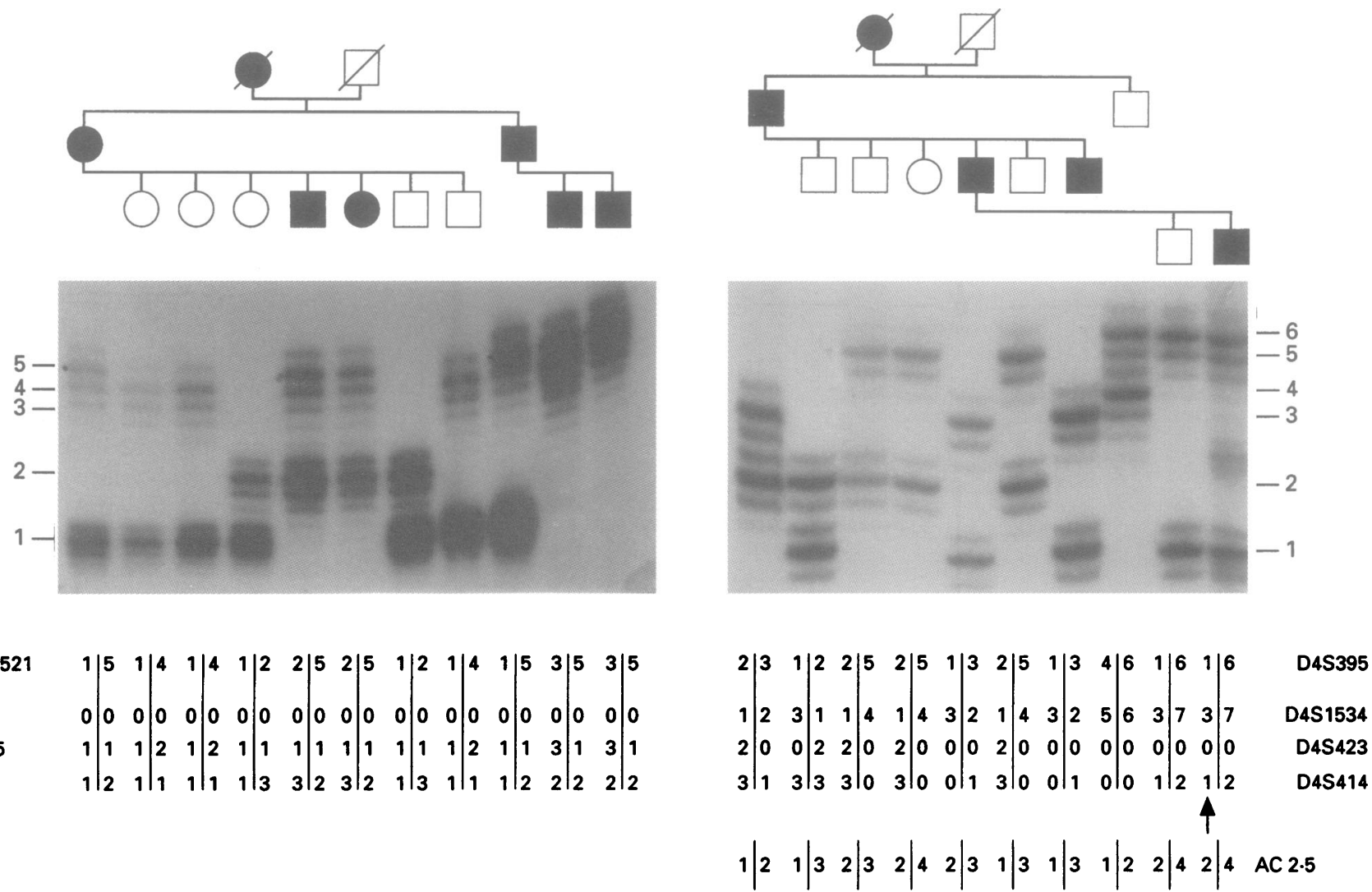

Figure 2 Microsatellite analysis of one ADPKD1 family (left) and one ADPKD2 family (right). Arrow indicates a recombinant chromosome that maps PKD2 between D4S1534 and D4S423.

showed significant differences. Only three out of the $16(18.75 \%)$ PKD1 mutation carriers younger than 20 years were free of renal cysts, compared to five out of the six (83.3\%) PKD2 mutation carriers in the same age group. The difference between both groups of patients was statistically significant $(\mathrm{p}<0 \cdot 01)$. When considering patients with renal cysts who are therefore at risk of developing secondary renal insufficiency, a difference between both groups was also found. Only $19 \%(6 / 31)$ of the ADPKD2 patients compared to $36 \%$ (27/74) of the ADPKD1 patients needed substitutive therapy. The difference was significant for the 31 to 40 year group, where no ADPKD2 patient $(0 / 12)$ and $57 \%(8 / 14)$ of the ADPKD1 patients had developed renal insufficiency $(\mathrm{p}<0 \cdot 002)$.

Table 2 Comparative incidences of ecographic cysts (cysts-), end stage renal disease (ESRD), and hypertension in genetic carriers (DNA+)

\begin{tabular}{|c|c|c|c|}
\hline Age (y) & $A D P K D 1$ & $A D P K D 2$ & $p^{*}$ \\
\hline $\begin{array}{r}0-10 \\
11-20 \\
21-30 \\
>31\end{array}$ & $\begin{array}{c}\text { Cyst - /DP } \\
1 / 1 \\
2 / 15 \\
0 / 19 \\
0 / 42\end{array}$ & $\begin{array}{l}1 / 1 \\
4 / 5 \\
0 / 6 \\
0 / 24\end{array}$ & $\begin{array}{l}\text { NS } \\
0.014 \\
\text { NS } \\
\text { NS }\end{array}$ \\
\hline $\begin{array}{l}21-30 \\
31-40 \\
41-50 \\
>51\end{array}$ & $\begin{array}{c}\text { ESRD/DN } \\
0 / 19 \\
8 / 14 \\
9 / 19 \\
8 / 9\end{array}$ & $\begin{array}{l}0 / 6 \\
0 / 12 \\
1 / 3 \\
5 / 9\end{array}$ & $\begin{array}{l}\text { NS } \\
0.002 \\
\text { NS } \\
\text { NS }\end{array}$ \\
\hline $\begin{array}{l}0-30 \\
31-40 \\
41-50 \\
>51\end{array}$ & $\begin{array}{c}\text { Hypertens } \\
3 / 35 \\
8 / 14 \\
10 / 19 \\
8 / 9\end{array}$ & $\begin{array}{l}\text { DNA + } \\
1 / 12 \\
1 / 12 \\
2 / 3 \\
3 / 9\end{array}$ & $\begin{array}{l}\text { NS } \\
0.012 \\
\text { NS } \\
0.003\end{array}$ \\
\hline
\end{tabular}

\section{Discussion}

Diagnosis in presymptomatic ADPKD carriers is frequently made by ultrasonography. However, false negative ultrasonographic diagnosis has been described..$^{20}$ In a previous study on our population we found that $22 \%$ of PKD1 mutation carriers younger than 30 years did not show renal cysts. ${ }^{21}$ This age dependence of manifestation of symptoms prompted several groups to develop DNA based protocols for family studies.

A different clinical course has been described for $\mathrm{ADPKD}$, with patients having the classical form (ADPKD1) showing renal cysts at an earlier age than those patients having mutations in a gene other than PKD1. ${ }^{1516}$ Previous studies on this topic have compared the classical form with a non-classical form, but the significance of these studies has been complicated by the lack of information on the genetic nature of the non-PKD1 form or forms of polycystic kidney disease. In our study comparison of both groups of patients showed significant differences, both in the age of cyst development and in the age of onset of end stage renal disease. The late development of renal cysts in ADPKD2 patients must be taken into account when performing echographical screening in these at risk subjects. This technique has to be considered as unreliable until later stages of life, and DNA polymorphic markers should be used as a screening tool in at risk ADPKD2 subjects younger than 30 years. The earlier development of renal cysts in ADPKD1 patients produces a faster deterioration of renal function and an earlier start 
of renal substitutive therapy. Hypertension was more frequent among ADPKD1 patients, confirming the previously suggested difference between the two forms of the disease. ${ }^{22}$

Finally, eight different $16 p$ haplotypes were found in the 12 ADPKD 1 families. To date only three mutations at PKD1 have been identified. ${ }^{7}$ If ADPKD 1 is the result of many different mutations, a direct approach for genetic counselling would be difficult and microsatellite analysis could be necessary for family studies.

We thank Drs D J M Peters, $M$ H Breuning, and J Weissenbach for providing information about some of the PCR primers.

1 Bear JC, McManamon P, Morgan J, et al. Age at clinical onset and at ultrasonographic detection of adult polycystic kidney disease: data for genetic counselling. $\mathrm{Am} 7 \mathrm{Med}$ Genet 1984;18:45-53.

2 Bear JC, Parfrey PS, Morgan JM, Martin CJ, Cramer BC. Autosomal dominant polycystic kidney disease: new information for genetic counselling. Am f Med Genet 1992, 43:548-53.

3 Reeders ST, Breuning MH, Davies KE, et al. A highly polymorphic DNA marker linked to adult polycystic kidpolymorphic DNA marker linked to adult polycystic kid-

4 Reeders ST, Breuning MH, Corney G, et al. Two genetic markers closely linked to adult polycystic kidney disease markers closely linked to adult polycystic kidn
on chromosome 16. BMF 1986;292:851-3.

5 Breuning MH, Reeders ST, Brunner H, et al. Improved early diagnosis of adult polycystic kidney disease with flanking DNA markers. Lancet 1987;ii: 1359-61.

6 Somlo S, Wirth B, Germino GG, et al. Fine genetic localization of the gene for autosomal dominant polycystic kidney disease (PKD1) with respect to physically mapped markers. Genomics 1992;13:152-8.

7 The European Polycystic Kidney Disease Consortium. The polycystic kidney disease 1 gene encodes a $14 \mathrm{~kb}$ transcrip and lies within a duplicated region on chromosome 16 . Cell 1994;77:881-94

8 Breuning MH, Snijdewint FGM, Brunner H, et al. Map of 16 polymorphic loci on the short arm of chromosome 16 close to the gene involved in polycystic kidney disease (PKD1). I Med Genet 1990;27:603-13.

9 Harris PC, Thomas S, Ratcliffe PJ, Breuning MH, Coto E, López-Larrea C. Rapid genetic analysis of families with polycystic kidney disease 1 by means of a microsatellite marker. Lancet 1991;338:1484-7.

10 Peral B, Ward CJ, San Millán JL, et al. Evidence of linkage disequilibrium in the Spanish polycystic kidney disease I population. Am F Hum Genet 1994;54:899-908.

11 Peters DJM, Spruit L, Saris JJ, et al. Chromosome 4 localization of a second gene for autosomal dominant polycystic kidney disease. Nature Genet 1993;5:359-62.

12 Kimberling WJ, Cumar S, Gabow PA, Kenyon JB, Connolly CJ, Somlo S. Autosomal dominant polycystic kidney disease: localization of the second gene to chromosome 4q13q23. Genomics 1993;18:467-72.

13 Kimberling WJ, Fain PR, Kenyon JB, Goldgar D, Sujansky E, Gabow PA. Linkage heterogeneity of autosomal domE, Gabow PA. Linkage heterogeneity of autosomal dominant poly-8.

14 Romeo G, Costa G, Catizone L, et al. A second genetic locus for autosomal dominant polycystic kidney disease. Lancet 1988;2:7-11.

15 Bear JC, Parfrey PS, Morgan J, et al. Autosomal dominant polycystic kidney disease: ultrasonographic detection and prognosis of PKD1 and PKD2 forms. Am f Med Genet 1989;45:39-43.

16 Parfrey PS, Bear JC, Morgan J, et al. The diagnosis and prognosis of autosomal dominant polycystic kidney disease. N Engl f Med 1990;323:1085-90.

17 Thompson AD, Shen Y, Holman K, Sutherland GR, Callen $\mathrm{DF}$, Richards RI. Isolation and characterisation of $(\mathrm{AC}) \mathrm{n}$ microsatellite genetic markers from human chromosome 16. Genomics 1992;13:402-8.

18 Lathrop GM, Lalouel JM. Easy calculations of lod scores and genetic risks on small computers. Am f Hum Genet and genetic risks

19 Fenton I, Sandkuijl LA. Megabase/PKD: a genetic database for polycystic kidney disease. In: Breuning MH, Devoto M, Romeo G, eds. Contributions to nephrology 97 . Polycystic kidney disease. Basel: Karger, 1992:118-27.

20 Ravine D, Gibson RN, Walker RG, Sheffield LJ, KincaidSmith P, Danks DM. Evaluation of ultrasonographic diagnosis criteria for autosomal dominant polycystic kidney disease 1. Lancet 1994;343:824-7.

21 Coto E, Aguado S, Alvarez J, Menéndez MJ, López-Larrea $\mathrm{C}$. Genetic and clinical studies in autosomal dominant polycystic kidney disease type I (ADPKD1). 7 Med Genet 1992;29:243-6.

22 Wright GD, Hughes AE, Larkin KA, Doherty CC, Nevin NC. Genetic linkage analysis, clinical features and prognosis of autosomal dominant polycystic kidney disease in Northern Ireland. $Q \mathcal{F}$ Med 1993;86:459-63. 